\title{
Effects of Grazing Intensity on Plant-Soil C: N: P Stoichiometry with Precipitation Changes During the Growing Season in Desert Grassland
}

\author{
Wei Yan (D 14747377177@163.com ) \\ Inner Mongolia Agriculture University: Inner Mongolia Agricultural University

\section{Fengling Shi} \\ Inner Mongolia Agriculture University: Inner Mongolia Agricultural University

\section{Tao Wan} \\ Inner Mongolia Agriculture University: Inner Mongolia Agricultural University
}

\section{Research Article}

Keywords: Precipitation, Grazing intensity, Nutrient ratios, Desert steppe, Ecological stoichiometry

Posted Date: November 10th, 2021

DOI: https://doi.org/10.21203/rs.3.rs-911986/v1

License: (c) (i) This work is licensed under a Creative Commons Attribution 4.0 International License. Read Full License 


\section{Abstract}

Background and aims

High-intensity grazing in the Mongolian grassland has led to the general deterioration of biodiversity and ecosystem functioning. Although abundant evidence shows that grazing affects the structure and function of grassland ecosystems, research on the impact of precipitation, especially under drought and overgrazing.

Methods

We examined the effects of heavy grazing, moderate grazing and no grazing on plant communities; plant and soil C, N and P contents; and plant and soil C:N:P stoichiometry in the desert grassland in different years with different amounts of precipitation.

Results

There was no significant difference in the species diversity between the grazing and no grazing treatment, while the no grazing treatment was significantly higher than the heavy grazing treatment. Compared with the amounts in the no grazing and moderate grazing treatments, the $\mathrm{N}$ and $\mathrm{P}$ contents of the plants in the heavy grazing treatment were the highest, and the $\mathrm{N}$ content of the soil increased. There was a positive correlation between precipitation and the $\mathrm{N}$ and $\mathrm{P}$ contents of plants and the $\mathrm{C}$ and $\mathrm{N}$ contents of the soil at $0-10 \mathrm{~cm}$ and $10-20 \mathrm{~cm}$.

\section{Conclusions}

Our study suggest that a large amount of precipitation of plant growth will drive changes in the community species diversity. Grazing promoted the flow of $\mathrm{N}$ between plants and the soil, especially under heavy grazing. Under grazing stress, plants maintain the potential of compensatory growth, and precipitation in the peak season of plant growth induces rapid growth, suggesting that precipitation is an important factor driving grazing ecosystems.

\section{Introduction}

Grassland ecosystems play an important role in regulating the climate and maintaining global biodiversity (Habel et al., 2013; Binder et al., 2018). Grazing is the most common land use in grassland ecosystems (Allred et al., 2011). In recent decades, under the continuous influence of human factors, large grassland areas on the Mongolian Plateau have been degraded to varying degrees (Wang et al., 2017). However, in desert grasslands where the average annual precipitation is less than $200 \mathrm{~mm}$ and long-term overgrazing occurs, plant communities remain stable and maintain a relatively high biomass (Wang et al., 2014a). Therefore, understanding the ecological process utilized by vegetation and soil in desert steppes under grazing stress is very important for the protection and management of plant species and for understanding community feedback and maintenance mechanisms.

As herbivores are responsible for rangeland degradation, it is obviously not tenable to explain plant response processes with livestock feeding. The existing literature suggests that grazing not only directly affects the community structure, primary productivity, biodiversity and ecosystem stability of grasslands (White et al., 2000; Schönbach et al., 2011; Cao et al., 2013) but also indirectly affects the chemical properties of soil (Cao et al., 2017) because livestock, vegetation and soil are complete micro-ecosystems. Soil stoichiometry can provide a good framework for such multilevel research. Stoichiometry can explain the energy balance of ecosystems and the interactions of various chemical elements within ecosystems. Stoichiometry provides a new perspective for exploring the biochemical cycles of specific populations, communities and ecosystems (Wang et al., 2014b) and reflects the adaptation strategies of plants in 
specific habitats (Sterner et al., 2002; Elser et al., 2000; Yan et al., 2016). Through the study of the C, N and P contents in plant leaves and $\mathrm{C}, \mathrm{N}$ and $\mathrm{P}$ stoichiometry, we can clearly understand the nutrients in the soil and the nutrient absorption and assimilation abilities in plants because there is usually a reciprocal nutritional relationship between plants and soil.

In addition, studies have shown that when large herbivores are present, precipitation is an important factor affecting community characteristics, especially in arid and rainless desert grasslands (Wang et al., 2014a; Bai et al., 2004). Water availability is the primary factor affecting the community structure and composition (Bai et al., 2012). Bai et al. (2004) suggested that precipitation from January to July was the main factor driving changes in grassland communities. However, the amount of precipitation in the desert steppe is far less than the amount of evaporation. If the precipitation period is not synchronous with the plant growth period or the time interval between the two periods is too long, precipitation cannot significantly affect the community (Westoby, 1998). Westoby (1998) assumed that changes in the community structure required special rainfall events, such as rare heavy rain. We hypothesize that the precipitation during the peak plant growth period will not significantly affect the characteristics of the community but will alter the essential nutrients in plants (e.g., C, N and P) and even in the soil.

Previous studies have focused on the changes of grass underground vegetation (such as the composition, structure, diversity and biomass) and soil characteristics (such as the water content and carbon storage) (Zhang et al., 2011; Jing et al., 2014). However, this study analysed the characteristics of plant communities and C: N: P stoichiometry in a desert steppe under different grazing treatments and precipitation distributions. Specifically, we addressed the following questions: 1) How do different grazing treatments affect the coverage, biomass, litter biomass and species richness of a plant community? 2) How do plant and soil C, N and P contents and stoichiometry respond to grazing treatments?

\section{Materials And Methods \\ 2.1 Study area}

The experimental area is located at the long-term grazing experiment site of the Stipa breviflora desert steppe of the Inner Mongolia Plateau. The geographical location of the study area is E $112^{\circ} 47^{\prime} 16.9^{\prime \prime}$ and N $42^{\circ} 16^{\prime} 26.2^{\prime \prime}$, and the elevation is $1100-1150 \mathrm{~m}$. The average temperature is $4.3^{\circ} \mathrm{C}$, the highest temperature is $38.7^{\circ} \mathrm{C}$, the lowest temperature is $-38.8{ }^{\circ} \mathrm{C}$, the winter is long and cold, the spring is dry and windy and the summer is hot. The frost-free period lasts approximately 130 days, with annual precipitation amounts ranging from 170 to $190 \mathrm{~mm}$ on average. More than $70 \%$ of the annual precipitation occurs in summer and autumn, and the annual evaporation rate is 2700 $\mathrm{mm}$. The soil is Kastanozem (FAO soil classification) with a sandy loam texture (Wang et al., 2014), and the humus content ranges from 1.0-1.8\%. Stipa breviflora Griseb. is the predominant species in the grassland. The dominant species are Cleistogenes songorica (Roshev.) Ohwi and Allium polyrhizum Turcz. ex Rege. The associated species are Convolvulus ammanii Desr., Kochia prostrata (L.) Schrad., Heteropappus altaicus (Willd.) Novopokr. and Neopallasia pectinate (Pall.) Poljak.

Years with more than $30 \%$ of the average precipitation are classified as wet years, and years with less than $30 \%$ of the average precipitation are classified as dry years. In this study, 2016 is a normal precipitation year, 2017 is a dry year and 2018 is a wet year (Table S1).

\subsection{Experimental design}


The grazing experiment was started in 1999. Grazing experiments began in May and ended in October. After the grazing experiments were completed, an enclosure was constructed to prevent interference from large herbivores. Three grazing treatments were established in the grazing experiment, and each treatment was repeated three times. The area of each plot was 2.60 ha. No grazing, moderate grazing and heavy grazing were accomplished with 0,5 and 8 sheep, respectively. The stocking rates for the three treatments were 0 sheep ha-1 $\mathrm{a}^{-1}, 1.92$ sheep ha $\mathrm{a}^{-1}$ and 3.08 sheep $\mathrm{ha}^{-1} \mathrm{a}^{-1}$, respectively. The weight, sex and health status of the sheep used in the experiment were similar (Liu et al., 2019).

\subsection{Data collection}

Field data were obtained from July 20 to August 10, which represented the period with the highest annual plant growth peaks in 2016, 2017 and 2018. In each treatment, five $1 \times 1 \mathrm{~m}$ quadrats were established randomly to observe the plant community coverage and species number, and then the aboveground biomass and litter biomass were clipped at the ground level. All plant materials in each sample were dried in an oven at $65^{\circ} \mathrm{C}$ for $48 \mathrm{~h}$ and weighed. The average total dry weight of each species, the number of species used to estimate the aboveground biomass and the species richness were calculated. Leaf samples of all species were collected in the same quadrat for the $\mathrm{C}, \mathrm{N}$ and $\mathrm{P}$ analysis (Bai et al., 2012).

Soil samples were obtained as composite samples from soil cores with a diameter of five $5 \mathrm{~cm}$ at depths of 0 to 10,10 to 20,20 to 30 and 30 to $40 \mathrm{~cm}$. The five cores from each quadrat were mixed in situ as one composite sample, and rocks and visible plant materials were removed by hand. The soil was air-dried and ground to pass through a $1 \mathrm{~mm}$ sieve for the $\mathrm{C}, \mathrm{N}$ and $\mathrm{P}$ analysis.

The total $\mathrm{C}$ and total $\mathrm{N}$ in the soil and plant samples were analysed with an Elementar Vario MACRO CUBE. The total $\mathrm{P}$ was determined by the $\mathrm{H}_{2} \mathrm{SO}_{4}-\mathrm{HClO}_{4}$ fusion method. Based on the content, the stoichiometries of the plant and soil samples, i.e., the ratios of C:N, C:P and N:P, were calculated.

Meteorological data were obtained from a micro weather station (GroWeather® software version 1.2; Davis Instruments Corporation, Hayward, CA, USA) located at the experimental site.

\subsection{Data analysis}

Analysis of variance (ANOVA) was used to examine the effects of grazing on the community coverage, biomass, litter biomass, species richness, plant C, N and P contents, plant C:N:P stoichiometry, soil C, N and P contents and soil C:N:P stoichiometry at different depths in 2016, 2017 and 2018. The grazing treatment, year and all interactions were used as fixed factors. The ANOVA was followed by Duncan's multiple range tests to compare grazing effects (Bai et al., 2012).

To analyse the driving factors affecting the community biomass and species richness, the partial least squares (PLS) method was used to construct regression equations. A regression equation for the community biomass, grazing treatment, precipitation during the peak period of plant growth and the $\mathrm{C}, \mathrm{N}$ and $\mathrm{P}$ contents and C:N:P stoichiometry of plants and soils at different depths was constructed. A regression equation for the species richness, grazing treatment, precipitation during the peak period of plant growth and the $\mathrm{C}, \mathrm{N}$ and $\mathrm{P}$ contents and C:N:P stoichiometry of plants and soils at different depths was also constructed. The variable importance of projection (VIP) was determined according to the regression equations. The greater the VIP value of the independent variable was, the stronger the influence of the independent variable on the community biomass and species richness was. If the independent VIP was $>1$, the independent variable was considered an important index; if the independent VIP was $<0.5$, the independent variable was considered a non-important index (Li et al., 2015).

Page $4 / 18$ 
To understand the relationship between precipitation during the peak period of plant growth and the $\mathrm{C}, \mathrm{N}$ and $\mathrm{P}$ contents and $\mathrm{C}: \mathrm{N}: \mathrm{P}$ stoichiometry of plants and soils at different depths, grazing was used as a fixed factor for a partial correlation analysis. The above statistical analyses were carried out in SAS 9.1 (SAS Institute Cary NC USA, 2003).

\section{Results}

\subsection{Coverage, biomass and species richness}

Precipitation during the peak period of plant growth significantly affected the plant community coverage, biomass, litter biomass and species richness (Table $1 ; P<0.05$ ), and grazing affected the plant community biomass and litter biomass. The community biomass and litter biomass were the highest in the non-grazing treatment, followed by those in the moderate grazing treatment and then the heavy grazing treatment (Fig. 1D-I), while the community coverage fluctuated greatly by year (Fig. 1A-C). There were no significant differences in the species richness values among the different grazing treatments in 2016 and 2017; however, the species richness under the heavy grazing treatment was significantly lower than that under the non-grazing treatment in 2018 (Fig. 1J-L; $P<0.05$ ).

Table 1

Repeated measures analysis of variance for coverage, community biomass, litter biomass and species richness using Grazing treatment, Precipitation during the peak season of plant growth, and interactions as fixed-effects.

\begin{tabular}{|lllll|}
\hline Response & Term & $\boldsymbol{d f}$ & $\boldsymbol{F}$ & $\boldsymbol{P}$ \\
\hline Coverage & Grazing treatment (G) & 2 & 0.51 & 0.60 \\
\cline { 2 - 5 } & Precipitation during the peak season of plant growth $(\mathrm{P})$ & 2 & 10.36 & $<0.001$ \\
\cline { 2 - 5 } & $\mathrm{G} \times \mathrm{P}$ & 4 & 8.27 & $<0.001$ \\
\hline Community biomass & $\mathrm{G}$ & 2 & 74.69 & $<0.001$ \\
\cline { 2 - 5 } & $\mathrm{P}$ & 2 & 36.33 & $<0.001$ \\
\cline { 2 - 5 } & $\mathrm{G} \times \mathrm{P}$ & 4 & 6.86 & $<0.001$ \\
\hline Litter biomass & $\mathrm{G}$ & 2 & 33.58 & $<0.001$ \\
\cline { 2 - 5 } & $\mathrm{P}$ & 2 & 4.74 & 0.01 \\
\cline { 2 - 5 } & $\mathrm{G} \times \mathrm{P}$ & 4 & 1.83 & 0.13 \\
\hline Species richness & $\mathrm{G}$ & 2 & 0.003 & 0.997 \\
\cline { 2 - 5 } & $\mathrm{P}$ & 2 & 14.18 & $<0.001$ \\
\cline { 2 - 5 } & $\mathrm{G} \times \mathrm{P}$ & 4 & 2.12 & 0.08 \\
\cline { 2 - 5 }
\end{tabular}

\subsection{C, N and P contents and C:N:P stoichiometry of plants}

Grazing significantly affected the plant $\mathrm{C}, \mathrm{N}$ and $\mathrm{P}$ contents (Table $2 ; P<0.05$ ). The $\mathrm{C}$ content proportion in plants under the no grazing treatment was $6.60 \%$ and $6.38 \%$ higher than that in plants under the heavy grazing treatment in 2016 and 2017 , respectively $(P<0.05)$, but no significant difference was found in 2018 . For the plant $\mathrm{N}$ and $\mathrm{P}$ contents, the heavy grazing treatment was the highest. The plant $\mathrm{N}$ content increased in 2018 for the three grazing treatments compared to 2016 and 2017. 
Table 2

Means and analysis of variance on the effects, their probability of grazing treatment in desert community of Inner Mongolia on plant C, N, P content and stoichiometry over 3 years. Means having a different lower case letter within a subset of a column are different $(P>0.05)$.

\begin{tabular}{|c|c|c|c|c|c|c|c|}
\hline & 2016 & 2017 & 2018 & All years & Effect & $\mathbf{F}$ & $\mathbf{P}$ \\
\hline \multicolumn{8}{|l|}{$C(\%)$} \\
\hline Heavy & $41.44 \mathrm{~b}$ & $42.39 \mathrm{~b}$ & 41.50 & $41.77 b$ & G & 8.04 & 0.003 \\
\hline Moderate & $42.61 \mathrm{ab}$ & $43.53 \mathrm{ab}$ & 41.51 & $42.55 \mathrm{ab}$ & $P$ & 12.32 & $<0.01$ \\
\hline Control & $44.17 \mathrm{a}$ & $45.09 \mathrm{a}$ & 41.40 & $43.55 \mathrm{a}$ & $G \times P$ & 2.27 & 0.10 \\
\hline \multicolumn{8}{|l|}{$\mathrm{N}(\%)$} \\
\hline Heavy & $2.95 a$ & 2.75 & $3.86 \mathrm{a}$ & $3.19 \mathrm{a}$ & $G$ & 10.89 & 0.001 \\
\hline Moderate & $2.63 a b$ & 2.33 & $3.35 a b$ & $2.77 a b$ & $P$ & 34.64 & $<0.01$ \\
\hline Control & $2.36 \mathrm{~b}$ & 2.35 & $3.15 b$ & $2.62 \mathrm{~b}$ & $G \times P$ & 0.39 & 0.81 \\
\hline \multicolumn{8}{|l|}{$\mathrm{P}(\%)$} \\
\hline Heavy & 0.21 & 0.20 & $0.21 \mathrm{a}$ & $0.21 \mathrm{a}$ & G & 4.64 & 0.02 \\
\hline Moderate & 0.20 & 0.10 & $0.15 b$ & $0.15 b$ & $\mathrm{P}$ & 1.33 & 0.29 \\
\hline Control & 0.18 & 0.21 & $0.16 a b$ & $0.18 a b$ & $G \times P$ & 2.35 & 0.09 \\
\hline \multicolumn{8}{|l|}{$C: N$} \\
\hline Heavy & $14.12 \mathrm{~b}$ & 15.71 & $10.85 b$ & $13.56 b$ & G & 12.47 & $<0.01$ \\
\hline Moderate & $16.26 \mathrm{ab}$ & 18.82 & $12.40 \mathrm{ab}$ & $15.83 a b$ & $\mathrm{P}$ & 36.07 & $<0.01$ \\
\hline Control & $18.72 \mathrm{a}$ & 19.20 & $13.14 \mathrm{a}$ & $17.02 \mathrm{a}$ & $G \times P$ & 0.72 & 0.59 \\
\hline \multicolumn{8}{|l|}{$C: P$} \\
\hline Heavy & $196.64 \mathrm{~b}$ & 215.21 & 203.13 & 204.99 & G & 2.36 & 0.12 \\
\hline Moderate & $210.93 a b$ & 570.33 & 282.62 & 354.63 & $\mathrm{P}$ & 1.62 & 0.23 \\
\hline Control & $251.34 \mathrm{a}$ & 238.90 & 268.37 & 252.87 & $G \times P$ & 1.65 & 0.21 \\
\hline \multicolumn{8}{|l|}{$N: P$} \\
\hline Heavy & 14.15 & 13.73 & 18.67 & 15.51 & $G$ & 1.88 & 0.18 \\
\hline Moderate & 13.01 & 31.19 & 22.89 & 22.36 & $\mathrm{P}$ & 1.67 & 0.22 \\
\hline Control & 13.39 & 12.49 & 20.36 & 15.42 & $G \times P$ & 1.32 & 0.30 \\
\hline
\end{tabular}

For the $\mathrm{C}: \mathrm{N}: \mathrm{P}$ stoichiometry, the $\mathrm{C}: \mathrm{N}$ ratio was affected by the grazing treatment and the amount of precipitation during the peak period of plant growth. The no grazing treatment had the highest ratio, followed by the moderate grazing treatment and then the heavy grazing treatment.

\subsection{C, N and P contents and C:N:P stoichiometry of soil}


Precipitation during the peak period of plant growth significantly affected the soil $\mathrm{C}, \mathrm{N}$ and $\mathrm{P}$ contents, while grazing affected only the soil $\mathrm{N}$ content (Table $3 ; P<0.05$ ). The soil $\mathrm{C}$ content at the $0-10 \mathrm{~cm}$ soil depth was significantly higher under the grazing treatment than under the no grazing treatment, while the $\mathrm{C}$ contents at the other soil depths were not significantly different. The soil $\mathrm{N}$ content under the grazing treatments tended to be higher than that under the no grazing treatment at all depths. In all 3 years, heavy grazing tended to produce the highest soil $\mathrm{N}$ content, followed by moderate grazing, and no grazing produced the lowest $\mathrm{N}$ content. Precipitation during the peak period of plant growth significantly affected the soil C:N, C:P and N:P ratios, and only the soil C:N ratio was affected by the grazing treatment (Table 4). 
Table 3

Means and analysis of variance on the effects, their probability of grazing treatment in desert community of Inner Mongolia on soil C, N, P content over 3 years. Means having a different lower case letter within a subset of a column are different $(P>0.05)$.

\begin{tabular}{|c|c|c|c|c|c|c|c|c|c|c|}
\hline \multirow[t]{2}{*}{ Year } & \multirow[t]{2}{*}{ Deep } & \multicolumn{3}{|l|}{$C(\%)$} & \multicolumn{3}{|l|}{ N (\%) } & \multicolumn{3}{|l|}{$P(\%)$} \\
\hline & & Heavy & Moderate & Control & Heavy & Moderate & Control & Heavy & Moderate & Control \\
\hline \multirow[t]{4}{*}{2016} & $\begin{array}{l}0- \\
10 \mathrm{~cm}\end{array}$ & 10.39 & 10.46 & 9.18 & $1.25 \mathrm{a}$ & $1.15 \mathrm{a}$ & $0.97 \mathrm{~b}$ & 0.49 & 0.36 & 0.72 \\
\hline & $\begin{array}{l}10- \\
20 \mathrm{~cm}\end{array}$ & $7.64 \mathrm{~b}$ & $9.41 \mathrm{ab}$ & $\begin{array}{l}12.33 \\
a\end{array}$ & 0.95 & 1.07 & 1.02 & 0.48 & 0.85 & 0.43 \\
\hline & $\begin{array}{l}20- \\
30 \mathrm{~cm}\end{array}$ & $6.11 \mathrm{~b}$ & $8.10 \mathrm{ab}$ & $\begin{array}{l}13.07 \\
a\end{array}$ & 0.79 & 0.93 & 0.95 & $\begin{array}{l}0.39 \\
a b\end{array}$ & $0.07 \mathrm{~b}$ & $0.54 \mathrm{a}$ \\
\hline & $\begin{array}{l}30- \\
40 \mathrm{~cm}\end{array}$ & 7.68 & 8.81 & 10.42 & 0.91 & 1.06 & 0.85 & 0.57 & 0.41 & 0.50 \\
\hline \multirow[t]{4}{*}{2017} & $\begin{array}{l}0- \\
10 \mathrm{~cm}\end{array}$ & $8.56 \mathrm{a}$ & $8.68 \mathrm{a}$ & $4.43 \mathrm{~b}$ & 1.02 & 1.10 & 0.70 & 0.61 & 0.88 & 0.83 \\
\hline & $\begin{array}{l}10- \\
20 \mathrm{~cm}\end{array}$ & $8.23 \mathrm{a}$ & $6.76 \mathrm{ab}$ & 4.98 b & $1.04 \mathrm{a}$ & $0.82 \mathrm{~b}$ & $0.76 \mathrm{~b}$ & 0.82 & 0.77 & 1.05 \\
\hline & $\begin{array}{l}20- \\
30 \mathrm{~cm}\end{array}$ & 7.51 & 7.49 & 6.70 & 0.97 & 0.90 & 0.85 & $0.64 \mathrm{~b}$ & $0.73 \mathrm{~b}$ & $1.04 \mathrm{a}$ \\
\hline & $\begin{array}{l}30- \\
40 \mathrm{~cm}\end{array}$ & 8.65 & 7.62 & 5.42 & 1.10 & 0.86 & 0.95 & 0.73 & 0.88 & 0.98 \\
\hline \multirow[t]{4}{*}{2018} & $\begin{array}{l}0- \\
10 \mathrm{~cm}\end{array}$ & 10.17 & 10.47 & 8.97 & 1.24 & 1.27 & 0.99 & 0.37 & 0.38 & 0.32 \\
\hline & $\begin{array}{l}10- \\
20 \mathrm{~cm}\end{array}$ & 9.25 & 8.65 & 9.70 & 1.14 & 1.04 & 0.93 & 0.34 & 0.29 & 0.32 \\
\hline & $\begin{array}{l}20- \\
30 \mathrm{~cm}\end{array}$ & 8.99 & 8.03 & 9.93 & 1.09 & 0.93 & 0.90 & 0.27 & 0.37 & 0.37 \\
\hline & $\begin{array}{l}30- \\
40 \mathrm{~cm}\end{array}$ & 8.88 & 7.72 & 10.13 & 1.09 & 0.95 & 0.74 & 0.36 & 0.36 & 0.32 \\
\hline \multirow[t]{4}{*}{$\begin{array}{l}\text { All } \\
\text { years }\end{array}$} & $\begin{array}{l}0- \\
10 \mathrm{~cm}\end{array}$ & $9.71 \mathrm{a}$ & $9.87 \mathrm{a}$ & 7.52 b & $1.17 \mathrm{a}$ & $1.17 \mathrm{a}$ & $0.89 \mathrm{~b}$ & 0.49 & 0.54 & 0.63 \\
\hline & $\begin{array}{l}10- \\
20 \mathrm{~cm}\end{array}$ & 8.37 & 8.28 & 9.00 & $1.04 \mathrm{a}$ & $0.97 a b$ & $0.90 \mathrm{~b}$ & 0.55 & 0.64 & 0.60 \\
\hline & $\begin{array}{l}20- \\
30 \mathrm{~cm}\end{array}$ & 7.54 & 7.87 & 9.90 & 0.95 & 0.92 & 0.90 & 0.44 & 0.39 & 0.65 \\
\hline & $\begin{array}{l}30- \\
40 \mathrm{~cm}\end{array}$ & 8.41 & 8.05 & 8.65 & 1.03 & 0.96 & 0.85 & 0.55 & 0.55 & 0.60 \\
\hline \multicolumn{2}{|l|}{ Effect } & $\mathrm{F}$ & $P$ & & $\mathrm{~F}$ & $P$ & & $\mathrm{~F}$ & $\mathrm{P}$ & \\
\hline \multicolumn{2}{|l|}{ G } & 0.19 & 0.82 & & 10.82 & 0 & & 1.71 & 0.19 & \\
\hline \multicolumn{2}{|l|}{$P$} & 14.92 & 0 & & 4.12 & 0.02 & & 30.93 & 0 & \\
\hline \multicolumn{2}{|c|}{ Depth (D) } & 0.58 & 0.63 & & 5.04 & 0.003 & & 0.68 & 0.57 & \\
\hline \multicolumn{2}{|l|}{$G \times P$} & 7.49 & 0 & & 2.12 & 0.09 & & 1.02 & 0.40 & \\
\hline
\end{tabular}




\begin{tabular}{|llllllll|}
\hline Year & Deep & $\mathbf{C}(\%)$ & & $\mathbf{N}(\%)$ & \multicolumn{3}{c|}{$\mathbf{P}(\%)$} \\
\hline $\mathrm{G} \times \mathrm{D}$ & 2.52 & 0.03 & 1.45 & 0.21 & 0.53 & 0.79 \\
$\mathrm{P} \times \mathrm{D}$ & 0.29 & 0.94 & 1.65 & 0.15 & 0.52 & 0.79 \\
\hline
\end{tabular}


Table 4

Means and analysis of variance on the effects, their probability of grazing treatment in desert community of Inner Mongolia on soil stoichiometry over 3 years. Means having a different lower case letter within a subset of a column are different $(P>0.05)$.

\begin{tabular}{|c|c|c|c|c|c|c|c|c|c|c|}
\hline Year & Deep & $C: N$ & & & $C: P$ & & & $N: P$ & & \\
\hline & & Heavy & Moderate & Control & Heavy & Moderate & Control & Heavy & Moderate & Control \\
\hline \multirow[t]{4}{*}{2016} & $\begin{array}{l}0- \\
10 \mathrm{~cm}\end{array}$ & 8.25 & 9.10 & 9.39 & 63.79 & 89.40 & 12.98 & 8.17 & 9.44 & 1.39 \\
\hline & $\begin{array}{l}10- \\
20 \mathrm{~cm}\end{array}$ & 8.06 b & $8.84 \mathrm{~b}$ & $\begin{array}{l}12.06 \\
a\end{array}$ & 45.12 & 19.87 & 60.52 & 5.73 & 2.16 & 4.70 \\
\hline & $\begin{array}{l}20- \\
30 \mathrm{~cm}\end{array}$ & 7.76 b & $8.71 a b$ & $\begin{array}{l}14.07 \\
a\end{array}$ & $\begin{array}{l}50.40 \\
a b\end{array}$ & $119.20 \mathrm{a}$ & $\begin{array}{l}25.31 \\
b\end{array}$ & $\begin{array}{l}6.27 \\
a b\end{array}$ & $13.99 \mathrm{a}$ & 1.81 b \\
\hline & $\begin{array}{l}30- \\
40 \mathrm{~cm}\end{array}$ & 8.44 & 8.37 & 11.98 & 14.56 & 45.42 & 65.08 & 1.77 & 5.68 & 6.69 \\
\hline \multirow[t]{4}{*}{2017} & $\begin{array}{l}0- \\
10 \mathrm{~cm}\end{array}$ & $8.34 \mathrm{a}$ & $7.90 \mathrm{a}$ & $6.35 b$ & 18.22 & 10.07 & 5.56 & 2.18 & 1.28 & 0.89 \\
\hline & $\begin{array}{l}10- \\
20 \mathrm{~cm}\end{array}$ & $\begin{array}{l}7.91 \\
a b\end{array}$ & $8.25 \mathrm{a}$ & $6.61 \mathrm{~b}$ & 10.35 & 8.89 & 6.08 & 1.30 & 1.08 & 0.90 \\
\hline & $\begin{array}{l}20- \\
30 \mathrm{~cm}\end{array}$ & 7.73 & 8.35 & 8.19 & $\begin{array}{l}12.07 \\
a\end{array}$ & $10.43 a b$ & $6.39 \mathrm{~b}$ & $1.54 \mathrm{a}$ & $1.26 \mathrm{ab}$ & 0.82 b \\
\hline & $\begin{array}{l}30- \\
40 \mathrm{~cm}\end{array}$ & 7.81 & 8.99 & 5.60 & $\begin{array}{l}11.97 \\
\mathrm{a}\end{array}$ & $8.51 \mathrm{ab}$ & $5.92 \mathrm{~b}$ & $1.53 \mathrm{a}$ & $0.95 b$ & 0.98 b \\
\hline \multirow[t]{4}{*}{2018} & $\begin{array}{l}0- \\
10 \mathrm{~cm}\end{array}$ & 8.14 & 8.27 & 9.18 & 26.92 & 28.06 & 28.94 & 3.31 & 3.40 & 3.28 \\
\hline & $\begin{array}{l}10- \\
20 \mathrm{~cm}\end{array}$ & 8.10 & 8.38 & 10.57 & 27.43 & 29.60 & 32.43 & 3.39 & 3.55 & 3.06 \\
\hline & $\begin{array}{l}20- \\
30 \mathrm{~cm}\end{array}$ & 8.21 & 8.64 & 11.38 & 34.53 & 21.85 & 28.14 & 4.22 & 2.54 & 2.61 \\
\hline & $\begin{array}{l}30- \\
40 \mathrm{~cm}\end{array}$ & 8.11 & 8.18 & 14.68 & 24.42 & 21.30 & 34.75 & 2.99 & 2.61 & 2.68 \\
\hline \multirow[t]{4}{*}{$\begin{array}{l}\text { All } \\
\text { years }\end{array}$} & $\begin{array}{l}0- \\
10 \mathrm{~cm}\end{array}$ & 8.25 & 8.42 & 8.31 & 36.31 & 42.51 & 15.83 & 4.55 & 4.71 & 1.85 \\
\hline & $\begin{array}{l}10- \\
20 \mathrm{~cm}\end{array}$ & 8.02 & 8.49 & 9.75 & 27.63 & 19.46 & 33.01 & 3.48 & 2.26 & 2.89 \\
\hline & $\begin{array}{l}20- \\
30 \mathrm{~cm}\end{array}$ & $7.90 \mathrm{~b}$ & $8.56 \mathrm{~b}$ & $\begin{array}{l}11.22 \\
\mathrm{a}\end{array}$ & 32.33 & 50.49 & 19.95 & 4.01 & 5.93 & 1.75 \\
\hline & $\begin{array}{l}30- \\
40 \mathrm{~cm}\end{array}$ & 8.12 & 8.51 & 10.75 & 16.98 & 25.08 & 35.25 & 2.10 & 3.08 & 3.45 \\
\hline Effect & & $\mathrm{F}$ & $P$ & & $\mathrm{~F}$ & $P$ & & $\mathrm{~F}$ & $P$ & \\
\hline G & & 10.07 & 0 & & 0.60 & 0.55 & & 1.47 & 0.24 & \\
\hline$P$ & & 10.53 & 0 & & 13.87 & 0 & & 12.08 & 0 & \\
\hline D & & 1.23 & 0.31 & & 0.39 & 0.76 & & 0.53 & 0.66 & \\
\hline$G \times P$ & & 8.33 & 0 & & 1.06 & 0.39 & & 1.14 & 0.34 & \\
\hline
\end{tabular}




\begin{tabular}{|lllllll|}
\hline Year & Deep & $\mathbf{C}: \mathbf{N}$ & \multicolumn{3}{c|}{$\mathbf{C}: \mathbf{P}$} & $\mathbf{N}: \mathbf{P}$ \\
\hline $\mathrm{G} \times \mathrm{D}$ & 1.44 & 0.21 & 1.31 & 0.27 & 1.11 & 0.37 \\
\hline $\mathrm{P} \times \mathrm{D}$ & 0.52 & 0.79 & 0.33 & 0.92 & 0.41 & 0.87 \\
\hline
\end{tabular}

3.4 Relationships among biomass, species richness and precipitation during the peak period of plant growth and the $C$, $\mathrm{N}$ and $\mathrm{P}$ contents and C:N:P stoichiometry

The VIP values showed that grazing and precipitation were important indicators of the community biomass and species richness (VIP > 1). Among them, the plant $\mathrm{N}$ content, the $\mathrm{C}: \mathrm{N}$ ratio and the $\mathrm{P}$ content in the soil at $0-20 \mathrm{~cm}$ were important factors affecting the species richness, while the soil $\mathrm{C}: \mathrm{N}$ ratio and the $\mathrm{N}$ content in the soil at $0-10 \mathrm{~cm}$ were important factors affecting the community biomass (Fig. 2; VIP > 1). Partial correlation analysis showed that precipitation during the peak period of plant growth was positively correlated with the plant $\mathrm{N}$ content and the soil $\mathrm{C}$ and $\mathrm{N}$ contents at $0-10 \mathrm{~cm}$ and $10-20 \mathrm{~cm}$ and negatively correlated with the plant $\mathrm{C}$ content, the $\mathrm{C}: \mathrm{N}$ ratio and the soil $\mathrm{P}$ content (Fig. 3).

\section{Discussion}

\subsection{Effects of grazing on community characteristics}

Grazing is a continuous and highly complex disturbance that can change the characteristics of grassland plant communities, such as the biomass and species diversity. In this study, community biomass and litter decreased as the grazing intensity increased, which was consistent with the results of Sun et al. (2013). The coverage of plant communities fluctuated greatly by year, especially in 2018 (wet year). The coverage under the heavy grazing treatment was $156 \%$ higher than that under the no grazing treatment, but the biomass under the heavy grazing treatment was $45 \%$ lower than that under the no grazing treatment. This result seems to be contradictory and may be due to the following reasons. 1) Precipitation can explain $55-86 \%$ of the variation in a plant community (Bai et al., 2012). During the analysis of the precipitation data, a large amount of continuous precipitation before the sampling period was noted. Continuous precipitation can lead to a surge in plant growth with relatively little interspecific competition under heavy grazing conditions, which is referred to as the "opportunism" strategy. During the process of observing the community coverage in the field, the coverage of these "opportunistic" plants was also measured, and the results showed an increased coverage in the heavily grazed communities. The individual moisture contents of these "opportunistic" plants increased; however, the biomass that accumulated in the community under heavy grazing was still lower than that under no grazing. 2) Most of the dominant species in the desert steppe are perennial clumped grasses. Although most of these species were consumed by the high-intensity livestock, a small number of leaves remained. Vegetation coverage is the proportion of the vertical projection area of vegetation to the surface area. During the observation of community coverage, although these perennial grasses contained very short leaves (very small biomass), their coverage accounted for a large proportion of the community coverage.

Westoby (1998) assumed that community succession requires special rainfall events, such as rare heavy rains, to drive community structure changes. This theory explains our research results very well because there was no significant difference in the community structure between the grazing and the no grazing treatments in 2016 and 2017, but the no grazing treatment had a significantly different structure than the heavy grazing treatment in 2018. Grazing makes the grassland appear to be low competition, increases the plant sites for plant seeds, improves the reproduction and distribution ranges of grazing-tolerant species and maintains species richness and livestock feeding in a delicate temporary steady state (Liu et al., 2017). In addition, the desert steppe is dry and rainless, the community 
structure is simple and the number of species is small. Thus, there was no significant difference in species richness among the grazing treatments. However, due to the continuous large amount of precipitation during the peak plant growth period in 2018, the "opportunistic" plants under the grazing treatments grew in large quantities and destroyed the relative balance between the other grassland species and livestock. The competitive disadvantage of the other grassland species coupled with the high-intensity feeding of livestock resulted in a decline in species richness under the grazing treatments, especially the heavy grazing treatment, in 2018.

\subsection{Effects of grazing on plant and soil $\mathrm{C}, \mathrm{N}$ and $\mathrm{P}$ pools}

Previous studies have suggested that for the studied species, nutrients are less affected by the environment and are relatively stable. Grazing changes the species composition, thereby altering the community stoichiometry because species have different nutrient components (Ritchie et al., 1998; Bardgett and Wardle, 2003). This theory supports our research to a certain extent; for example, in 2016 and 2017, the plant C contents were the highest under the no grazing treatment, followed by the moderate grazing and heavy grazing treatments, while there were no significant differences in $\mathrm{C}$ contents in 2018. In addition, these results may be due to the characteristics of desert grassland plants and their adaptation to grazing disturbances. The most prominent climatic characteristics in arid areas are the scarcity of precipitation and the large inter-annual and inter-seasonal variations. In drought years, the leaf area and leaf width showed a decreasing trend. In contrast, the leaf area and leaf length showed a preferential growth characteristic in wet years (Balota et al., 2008; Picotte et al., 2009). Most of the plants in the desert steppe belong to radical leaf- and stemfree supporting structures. Therefore, there was no significant difference in the leaf $\mathrm{C}$ content under the abundant precipitation in 2018. In 2016 and 2017, due to intensive heavy grazing, plants usually avoided grazing by reducing their height, which changed their $\mathrm{C}$ assimilation and accumulation abilities.

In addition, the results showed that plants under the heavy grazing treatment had higher $\mathrm{N}$ and $\mathrm{P}$ contents in plant leaves than those under the no grazing and moderate grazing treatments. We propose the following potential mechanisms to explain these phenomena. Plants induce livestock to feed on plant tissues, organs or populations with low $\mathrm{P}$ and $\mathrm{N}$ contents (Sun et al., 2014). Sheep feeding not only stimulates the growth of pasture plants but also promotes the redistribution of $\mathrm{N}$ and $\mathrm{P}$ to young organs, thus increasing the $\mathrm{N}$ and $\mathrm{P}$ contents in living plants under grazing treatments, leading to the maximum average $\mathrm{N}$ and $\mathrm{P}$ contents under heavy grazing conditions. This phenomenon implies that plants manipulate the nutrient cycle by altering the diet of livestock to a certain extent. In the desert steppe, a large amount of precipitation will significantly increase the water content of plant leaves. The daily evaporation of the desert steppe is very high, which means that large amounts of precipitation will increase the evaporation capacity of plants per unit time (the transpiration tension is strengthened). Higher transpiration rates will promote the synthesis of more N-rich transporters in roots for transporting nutrients to compensate for the plant leaves. To support the rapid growth of plants, ribosomes must rapidly synthesize protein, which means that plants must allocate more $\mathrm{P}$ to rRNA, which improves growth rates and increases the $\mathrm{N}$ and $\mathrm{P}$ contents in plants.

By analysing the soil $\mathrm{N}$ content, it was found that the soil $\mathrm{N}$ content under the heavy grazing treatment was higher than that under the no grazing treatment, and this is consistent with Bai et al. (2012). This result indicates that $\mathrm{N}$ is in a circulating state in heavy grazing ecosystems. This may be because grazing increases C-rich root exudates that stimulate microbial activity and transformation, ultimately leading to an increased availability of soil nutrients to plants (Bardgett et al., 1998; Hamilton and Frank, 2001). These results imply that grazing can accelerate the soil $\mathrm{N}$ cycle in desert grasslands. First, grazing can increase nutrient cycling by stimulating microbial activity by importing fresh plant litter and animal excreta (Holland, Cheng \& Crossley, 1996; Hamilton \& Frank, 2001). Second, grazing may induce plant avoidance strategies to produce higher concentrations of defence compounds to reduce nutrient losses (hobbie 1992; Ritchie, Tilman \& Knops, 1998). These theories support our results to some extent. Further, research has shown that the $\mathrm{C}: \mathrm{N}$ ratio in soil can reveal the relationship between the transformation of carbon and nitrogen during 
soil biological decomposition. When the soil C:N ratio was between 5.6 and 11.3 , the soil microbial biomass began to increase, and soil $\mathrm{N}$ mineralization increased significantly. When the $\mathrm{C}: \mathrm{N}$ ratio was between 15.3 and 20.6 , the soil microbial biomass increased rapidly, organic matter decomposition weakened and mineralized $\mathrm{N}$ was released (Gundersen et al., 1998). In this study, compared with the no grazing treatment, the soil C:N ratios under the heavy grazing and moderate grazing treatments were in the range of 5.6-11.3, which further verified that grazing accelerated the flow and transformation of $\mathrm{N}$ in the soil.

Based on the analysis of the $\mathrm{C}, \mathrm{N}$ and $\mathrm{P}$ contents in plants, we propose that plants under grazing conditions, especially heavy grazing, may adapt to a severe living environment in the following ways. Under long-term grazing stress, plants can induce livestock to eat specific plant tissues and organs or plant species with low $\mathrm{N}$ and $\mathrm{P}$ contents. To continue to grow and reproduce, the surviving plants must remain in a relatively stable maintenance state (because the rapid growth of plants requires the synthesis of a large amount of proteins and RNA, which requires them to have high $\mathrm{N}$ and $\mathrm{P}$ contents). Partial correlation analysis revealed that precipitation was positively correlated with plant $\mathrm{N}$ and $\mathrm{P}$ contents, suggesting that precipitation was the "trigger" that disrupted the equilibrium. In the soil, accelerated $\mathrm{N}$ cycling could meet the $\mathrm{N}$ needs for plant growth, and precipitation was positively correlated with the $\mathrm{C}$ and $\mathrm{N}$ contents in the 0 $20 \mathrm{~cm}$ soil layer, suggesting that precipitation is an important factor driving the changes in grazing ecosystems. Our results further validate the hypothesis that grazing and precipitation are important indicators of community biomass and species richness.

\section{Conclusions}

The results indicated that in the desert steppe, abundant precipitation during the peak period of plant growth could induce changes in the community species composition. Grazing promoted the flow of $\mathrm{N}$ between plants and soil, especially under heavy grazing. Under grazing stress, plants maintain the potential of compensatory growth with high $\mathrm{N}$ and $\mathrm{P}$ contents, and precipitation in the peak season of plant growth induces rapid growth, suggesting that precipitation is an important factor driving grazing ecosystems.

\section{Declarations}

\section{Acknowledgements}

This research was supported by the Research Program of Science and Technology at Universities of Inner Mongolia Autonomous Region (2019ZD997).

\section{References}

1. Allred BW et al (2011) The role of herbivores in Great Plains conservation: Comparative ecology of bison and cattle. Ecosphere 2:26

2. Bai YF et al (2004) Ecosystem stability and compensatory effects in the Inner Mongolia grassland. Nature 431:181-184

3. Bai YF et al (2012) Grazing alters ecosystem functioning and C:N:P stoichiometry of grasslands along a regional precipitation gradient. J Appl Ecol 49:1204-1215

4. Balota $\mathrm{M}$ et al (2008) Morphological and physiological traits associated with canopy temperature depression in three closely related wheat lines. Crop Sci 48:1897-1910 
5. Bardgett RD, Wardle DA (2003) Herbivore-mediated linkages between aboveground and belowground communities. Ecology 84:2258-2268

6. Bardgett RD et al (1998) Linking aboveground and below-ground interactions: how plant responses to foliar herbivory influence soil organisms. Soil Biol Biochem 30:1867-1878

7. Binder S et al (2018) Grassland biodiversity can pay. Proc Natl Acad Sci USA 115:3876-3881

8. Cao JJ et al (2017) Impact of grassland contract policy on soil organic carbon losses from alpine grassland on the Qinghai-Tibetan Plateau. Soil Use Manag 33:663-671

9. Cao JJ et al (2013) The effects of enclosures and land-use contracts on rangeland degradation on the QinghaiTibetan Plateau. J Arid Environ 97:3-8

10. Elser JJ et al (2000) Biological stoichiometry from genes to ecosystem. Ecol Lett 3(6):540-555

11. Gundersen P et al (1998) Impacts of nitrogen deposition on N cycling:a synthesis of NITREX data. For Ecol Manage 101:37-55

12. Habel JC et al (2013) European grassland ecosystems: threatened hotspots of biodiversity. Biodivers Conserv 22:2131-2138

13. Hamilton EW, Frank DA (2001) Can plants stimulate soil microbes and their own nutrient supply? Evidence from a grazing tolerant grass. Ecology 82:2397-2402

14. Jing et al (2014) Changes in plant community composition and soil properties under 3-decade grazing exclusion in semiarid grassland. Ecol Eng 64:171-178

15. Kerkhoff A et al (2006) Phylogenetic and Growth Form Variation in the Scaling of Nitrogen and Phosphorus in the Seed Plants. Am Nat 168:103-122

16. Li X et al (2015) Pathways of Leymus chinensis Individual Aboveground Biomass Decline in Natural Semiarid Grassland Induced by Overgrazing: A Study at the Plant Functional Trait Scale. Plos One, 10. e0124443

17. Liu WT et al (2017) The impacts of grazing on plant diversity in Stipa breviflora desert grassland. Acta Ecol Sin 37(10):3394-3402

18. Liu WT et al (2019) Maintenance of dominant populations in heavily grazed grassland: Inference from a Stipa breviflora seed germination experiment. PeerJ 7:e6654

19. Picotte JJ et al (2009) Leaf morphological responses to variation in water availability for plants in the Piriqueta caroliniana complex. Plant Ecol 200:267-275

20. Reef $R$ et al (2010) Relationships among RNA: DNA ratio, growth and elemental stoichiometry in mangrove trees. Funct Ecol 24(5):1064-1072

21. Ritchie ME et al (1998) Herbivore effects on plant and nitrogen dynamics in oak savanna. Ecology 79:165-177

22. Schönbach et al (2011) Grassland responses to grazing: effects of grazing intensity and management system in an Inner Mongolian steppe ecosystem. Plant Soil 340:103-115

23. Sterner RW, Elser J (2002) Ecological Stoichiometry: The Biology of Elements from Molecules to the Biosphere. Princeton University Press, Princeton, p 439

24. Sun SX et al (2014) Effects of seasonal regulation of grazing intensity on $\mathrm{N}$ and $\mathrm{C}$ of main plant species and soil in desert grassland. Chinese journal of Grassland 36:49-54

25. Sun SX et al (2013) Characteristics of plant community and its functional groups in desert grassland under effects of seasonal regulation of grazing intensity. Chin J Ecol 32(10):2703-2710

26. Wang Z et al (2014a) Effects of stocking rate on the variability of peak standing crop in a desert steppe of Eurasia grassland. Environ Manage 53:266-273

Page $14 / 18$ 
27. Wang $Z$ et al (2017) What is the main cause of grassland degradation? A case study of grassland ecosystem service in the middle-south Inner Mongolia. Catena 150:100-107

28. Wang W et al (2014b) Temporal changes in SOM, N, P, K and their stoichiometric ratios during reforestation in China and interactions with soil depths: Importance of deep-layer soil and management implications. For Ecol Manage 325:8-17

29. Westoby M (1989) Opportunistic Management for Rangelands Not at Equilibrium. J Range Manag 42:266-274

30. White R et al (2000) Pilot Analysis of Global Ecosystems: Grassland Ecosystems. World Resources Institute, Washington DC

31. Yan W et al (2016) Linking plant leaf nutrient/stoichiometry to water use efficiency on the Loess Plateau in China. Ecol Eng 87:124-131

32. Zhang C et al (2011) A comparison of soil qualities of different revegetation types in the Loess Plateau, China. Plant Soil 347(1-2):163-178

\section{Figures}



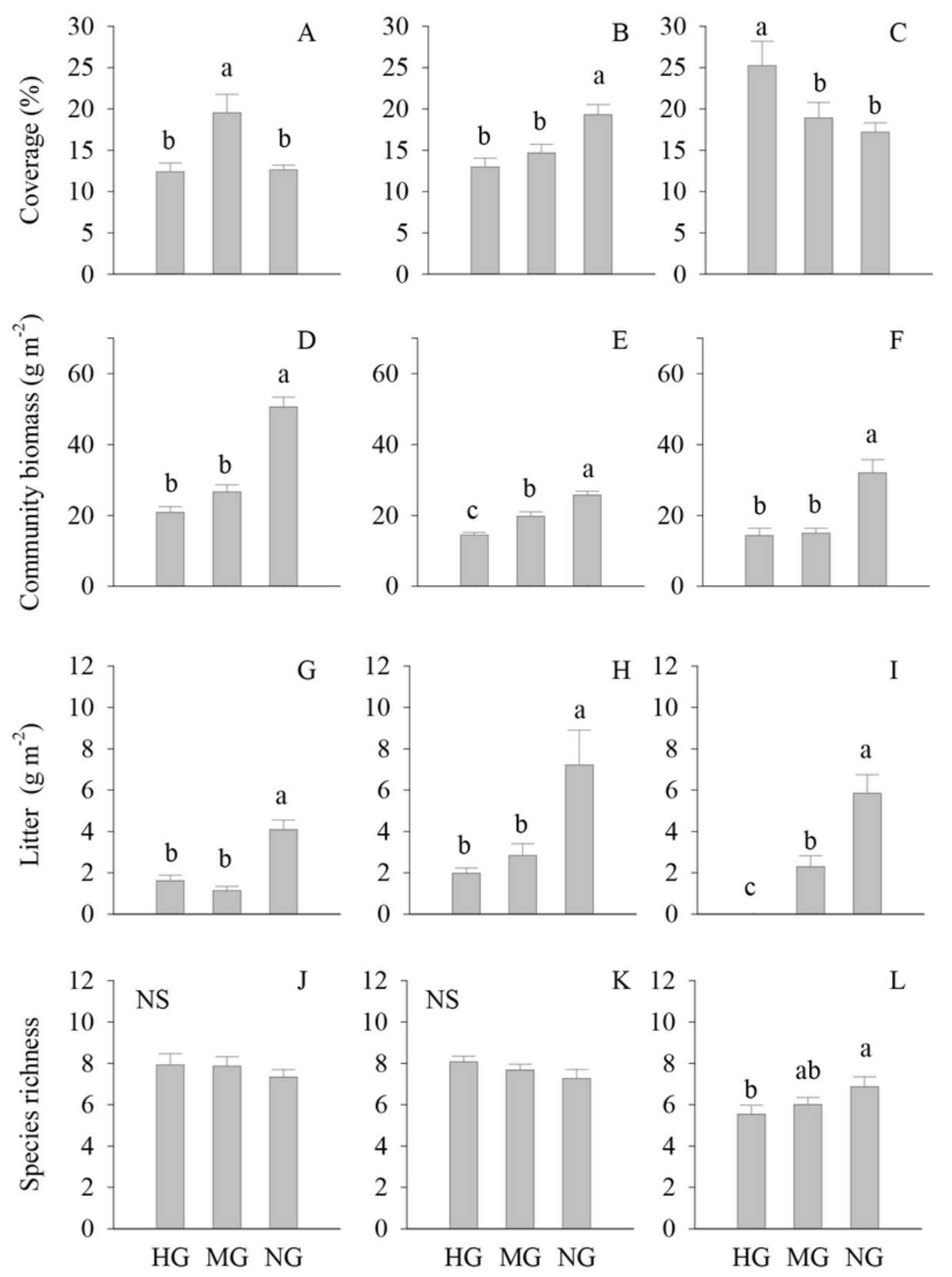

Grazing treatment

Figure 1

Effects of grazing on the community coverage, biomass, litter biomass and species richness (error bars are denoted by $\mathrm{SE})$. Bars with the same letter were not significantly different in Duncan's multiple range tests reported from one-way ANOVA, and NS indicates non-significant $(P>0.05)$. 


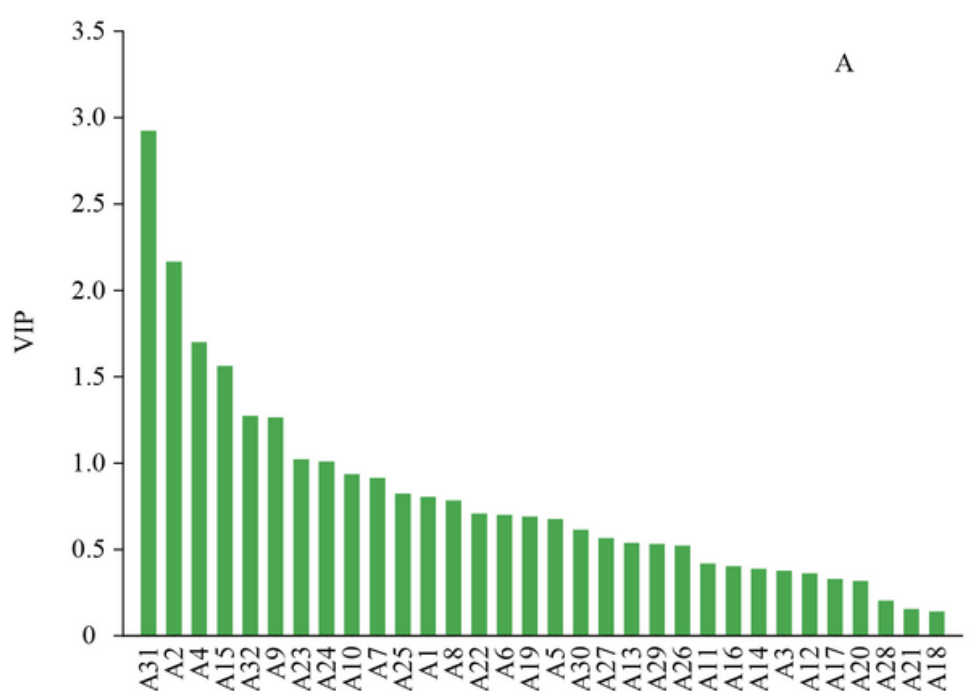

Indicator

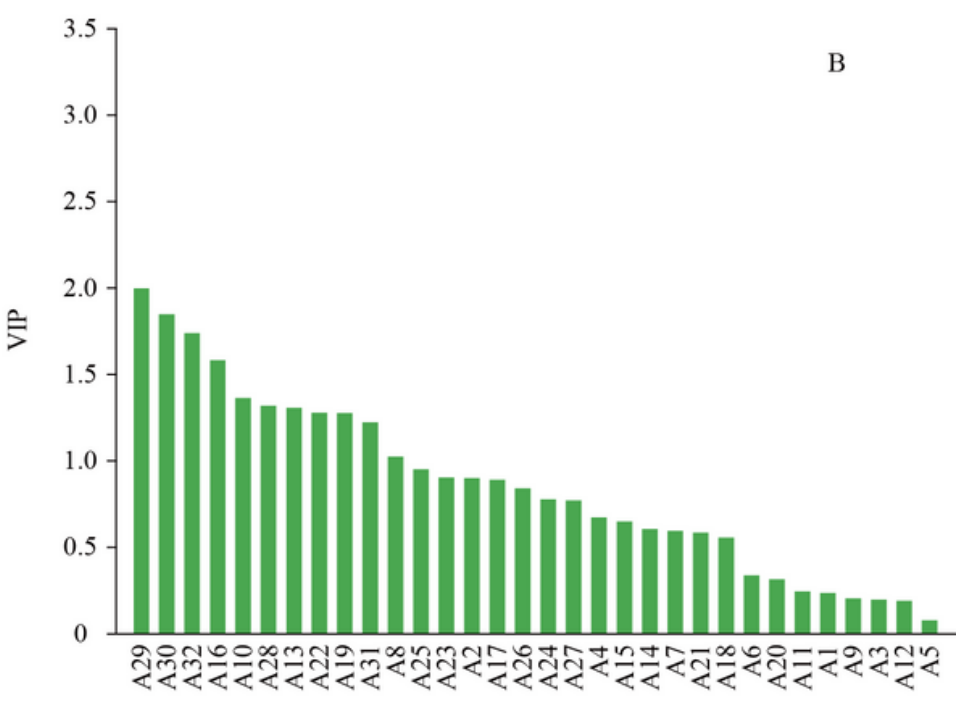

Indicator

Figure 2

VIP values of indicator of plant and soil $C, N, P$ and stoichiometry with respect to species richness $(A)$ and community biomass (B). A1, plant C content; $A 2$, plant N content; $A 3$, plant P content; A4, plant C:N; A5, plant C:P; A6, plant N:P; A7, $C$ content in $0-10 \mathrm{~cm}$ soil; $A 8, N$ content in $0-10 \mathrm{~cm}$ soil; $A 9, P$ content in 0-10cm soil; $A 10, C: N$ in $0-10 \mathrm{~cm}$ soil; $A 11, C: P$ in 0-10cm soil; A12, N:P in 0-10cm soil; A13, C content in 10-20 cm soil; A14, N content in 10-20cm soil; A15, P content in 10-20cm soil; A16, C:N in 10-20cm soil; A17, C:P in 10-20cm soil; A18, N:P in 10-20cm soil; A19, C content in 20-30cm soil; A20, $\mathrm{N}$ content in $20-30 \mathrm{~cm}$ soil; $\mathrm{A} 21$, $\mathrm{P}$ content in $20-30 \mathrm{~cm}$ soil; $\mathrm{A} 22, \mathrm{C}: \mathrm{N}$ in $20-30 \mathrm{~cm}$ soil; A23, C:P in 20-30 cm soil; A24, N:P in $20-30 \mathrm{~cm}$ soil; $A 25, C$ content in $30-40 \mathrm{~cm}$ soil; $A 26, N$ content in $30-40 \mathrm{~cm}$ soil; $A 27, P$ content in $30-40 \mathrm{~cm}$ soil; $\mathrm{A} 28, \mathrm{C}: \mathrm{N}$ in $30-40 \mathrm{~cm}$ soil; $\mathrm{A} 29, \mathrm{C}: \mathrm{P}$ in $30-40 \mathrm{~cm}$ soil; $\mathrm{A} 30, \mathrm{~N}: \mathrm{P}$ in $30-40 \mathrm{~cm}$ soil; $\mathrm{A} 31$, precipitation during the peak season of plant growth; $A 32$, grazing.

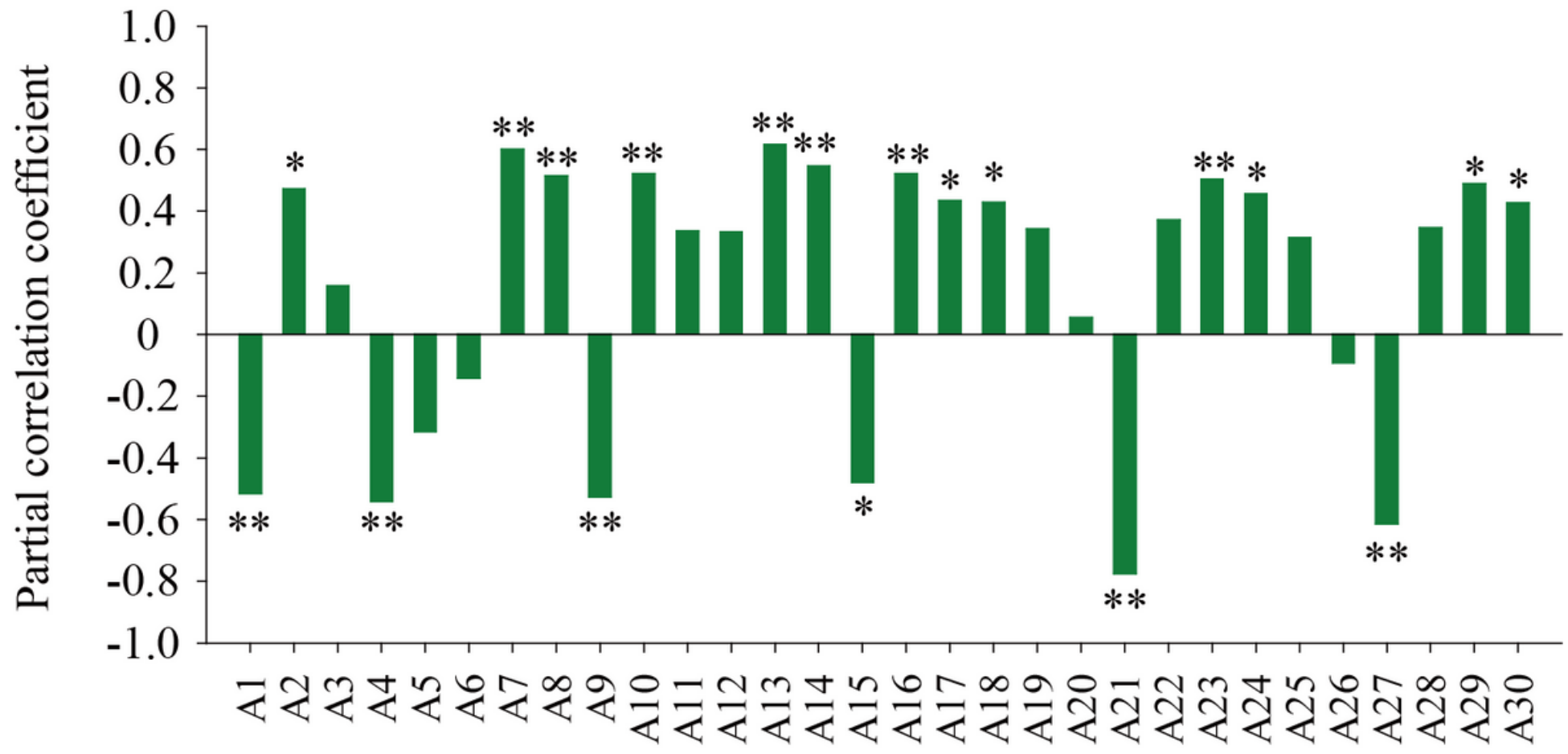




\section{Figure 3}

Partial correlation relationship between the precipitation during the peak season of plant growth and the $\mathrm{C}, \mathrm{N}$ and $\mathrm{P}$ contents and stoichiometry of plants and soil. *, $P<0.05$; ${ }^{*}, P<0.01$. $A 1$, plant $C$ content; $A 2$, plant $N$ content; $A 3$, plant $P$ content; A4, plant C:N; A5, plant C:P; A6, plant N:P; A7, C content in the 0-10 cm soil; A8, $\mathrm{N}$ content in the 0-10 cm soil; A9, P content in the 0-10 cm soil; A10, C:N in the 0-10 cm soil; A11, C:P in the 0-10 cm soil; A12, N:P in the 0-10 cm soil; A13, C content in the $10-20 \mathrm{~cm}$ soil; $A 14, N$ content in the $10-20 \mathrm{~cm}$ soil; $A 15, P$ content in the $10-20 \mathrm{~cm}$ soil; $A 16, C: N$ in the 10-20 cm soil; A17, C:P in the 10-20 cm soil; A18, N:P in the $10-20 \mathrm{~cm}$ soil; A19, C content in the 20-30 cm soil; $A 20$, $\mathrm{N}$ content in the $20-30 \mathrm{~cm}$ soil; $A 21, \mathrm{P}$ content in the $20-30 \mathrm{~cm}$ soil; $\mathrm{A} 22, \mathrm{C}: \mathrm{N}$ in the $20-30 \mathrm{~cm}$ soil; $A 23, \mathrm{C}: \mathrm{P}$ in the 20-30 $\mathrm{cm}$ soil; $\mathrm{A} 24, \mathrm{~N}: \mathrm{P}$ in the $20-30 \mathrm{~cm}$ soil; A25, C content in the $30-40 \mathrm{~cm}$ soil; $A 26, \mathrm{~N}$ content in the $30-40 \mathrm{~cm}$ soil; $A 27, P$ content in the $30-40 \mathrm{~cm}$ soil; $A 28, \mathrm{C}: \mathrm{N}$ in the $30-40 \mathrm{~cm}$ soil; $A 29, \mathrm{C}: \mathrm{P}$ in the $30-40 \mathrm{~cm}$ soil; $\mathrm{A} 30, \mathrm{~N}: \mathrm{P}$ in the $30-40 \mathrm{~cm}$ soil.

\section{Supplementary Files}

This is a list of supplementary files associated with this preprint. Click to download.

- TableS1.docx 